\title{
Articles
}

\section{REREADING WARREN AND BRANDEIS: Privacy, Property, AND APPROPRIATION}

\author{
Robert C. Post*
}

REREADING WARREN AND BRANDEIS," as one must on this hundredth anniversary of their "monumental article,"2 comes as something of a shock. The prestige and enormous influence of the piece ${ }^{3}$ creates expectations of sweeping vistas and irresistible arguments. But, setting aside the rhetorically powerful (and often quoted) passages of complaint against the irresponsibility of the press, ${ }^{4}$ the article offers instead a technical and rather dry exposition of the legal rights of unpublished authors and art-

* Professor of Law, School of Law (Boalt Hall), Unıversity of Californıa at Berkeley. I am grateful to the many friends and colleagues who have read this essay and improved it through their useful and constructive suggestions: David Anderson, Steve Barnett, John Dwyer, Melvin Eisenberg, John Fleming, Ruth Gavison, Sheldon Halpern, Sheldon Messınger, Frank Michelman, Paul Mishkın, Andrea Peterson, Mark Rose, Ferdinand Schoeman, Jerome Skolntck, and Ragesh Tangrı.

1. Warren \& Brandeis, The Right to Privacy, 4 Harv. L. Rev. 193 (1890).

2. Gordon, Right of Property in Name, Likeness, Personality and History, $55 \mathrm{Nw}$. U.L. REV. 553, 553 (1960).

3. See, e.g., Kalven, Privacy in Tort Law-Were Warren and Brandeis Wrong?, 31 Law \& Contemp. Probs. 326, 327 (1966); Prosser, Privacy, 48 Calif. L. Rev. 383, 383 (1960).

4. Compare Cox Broadcasting Corp. v. Cohn, 420 U.S. 469, 487 n.16 (1975), with Godkın, The Right to Privacy, 51 Nation 496, 496 (1890). 
ists. The argument that carries the actual work of the article is intended to demonstrate that the law of common law copyright, usually conceptualized in terms of property, should rather be seen as resting on "the right to privacy, as a part of the more general right to the immunity of the person, the right to one's personality."'s

In fact the central thrust of Warren and Brandeis's article on "the right to privacy" is to disentangle privacy from property, and the subsequent influence of the piece rests in great measure upon its success in that effort. As one court remarked, duly noting the leading contribution of Warren and Brandeis's article: "Basically, recognition of the right to privacy means that the law will take cognizance of an injury, even though no right of property or contract may be involved and even though the damages resulting are exclusively those of mental anguish."

There is no small irony in this. Warren and Brandeis acknowledged as one of the chief motivations for their article the "feeling," which had been growing "[f]or years," that "the law must afford some remedy for the unauthorized circulation of portraits of private persons." They therefore advanced as the "simplest case" of their proposed right of privacy the "right of one who has remained a private individual, to prevent his public portraiture." claim against "public portraiture" did so explicitly on the grounds that "one has an exclusive right to his picture, on the score of its being a property right of material profit."

Moreover seventy years after the publication of The Right to Privacy, when William. Prosser magisterially divided the privacy tort ${ }^{10}$ into four distinct causes of action, ${ }^{11}$ he wrote that "appro-

5. Warren \& Brandeis, supra note 1 , at 207.

6. Eick v. Perk Dog Food Co., 347 Ill. App. 293, 299, 106 N.E.2d 742, 745 (1952); see Fairfield v. American Photocopy Equip. Co., 138 Cal. App. 82, 85, 291 P.2d 194, 199 (1955).

7. Warren \& Brandeis, supra note 1 , at 195.

8. Id. at 213.

9. Munden v. Harris, 153 Mo. App. 652, 660, 134 S.W. 1076, 1079 (1911); see Edison v. Edison Polyform \& Mfg. Co., 73 N.J. Eq. 136, 143, 67 A. 392, 395 (N.J. Ch. 1907).

10. The privacy tort was initially undifferentiated. See RESTATEMENT OF TORTS $\S$ 867 (1939):

Section 867. Interference with Privacy

A person who unreasonably and seriously interferes with another's interest in not having his affairs known to others or his likeness exhibited to the public is liable to the other. 
priation," or the claim that a defendant has taken "for the defendant's advantage, . . . the plaintiff's name or likeness," ought to be founded upon an interest that is "not so much a mental as a proprietary one, in the exclusive use of the plaintiff's name and likeness as an aspect of his identity."12 What we now call the tort of appropriation, ${ }^{13}$ what Warren and Brandeis would have called the right to prevent public portraiture, has thus all along lurched precariously between formulations of privacy and of property. ${ }^{14}$

This ambiguous history calls into question precisely the stakes in Warren and Brandeis's original attempt to distinguish privacy from property. What difference, we might ask, does it make whether the tort of appropriation is conceived as a property rather than as a personal right? The answer, perhaps, lies in a close rereading of Warren and Brandeis's pathbreaking work.

\section{Privacy and Personality}

A central claim of The Right to Privacy is that "[t] he princi-

11. Prosser, supra note 3, at 389. Prosser's distinctions were later adopted by the second Restatement. See Restatement (SECOND) OF TORTS § 652A (1976):

Section 652A. General Principle

(1) One who invades the right of privacy of another is subject to liability for the resulting harm to the interests of the other.

(2) The right of privacy is invaded by

(a) unreasonable intrusion upon the seclusion of another, as stated in $\S 652 \mathrm{~B}$; or

(b) appropriation of the other's name or likeness, as stated in $\S$ $652 \mathrm{C}$; or

(c) unreasonable publicity given to the other's private life, as stated in $\S 652 \mathrm{D}$; or

(d) publicity that unreasonably places the other in a false light before the public, as stated in $\S 652 \mathrm{E}$.

12. Prosser, supra note 3, at 389,406 . Following Prosser, the Restatement (Second) of Torts notes that appropriation creates "a property right, for the exercise of which an exclusive license may be given to a third person, which will entitle the licensee to maintain an action to protect it." Restatement (SECOND) OF TORTS § 652C comment a. For the drafters of the second Restatement, this third party right of action constituted an important distinction between the appropriation branch of the tort and its three siblings. See id. $\S 6521$ comment a.

13. See Restatement (SECOND) of ToRTs $\$ 652 \mathrm{C}$ ("One who appropriates to his own use or benefit the name or likeness of another is subject to liability to the other for invasion of his privacy.").

14. For a discussion of this ambivalence, see Candebat v. Flanagan, 487 So. 2d 207 (Miss. 1986). Compare Hinish v. Meier \& Frank Co., 166 Or. 482, 492-93, 113 P.2d 438, 446 (1941) (unnecessary to search for property right when determining whether defendant invaded plaintiff's right to privacy by forging plaintiff's signature), with Hirsch v. S.C. Johnson \& Son, Inc., 90 Wis. 2d 379, 387, 280 N.W.2d 129, 134 (1979) (appropriation protects a property right in the publicity value of a person's identity). 
ple which protects personal writings and all other personal productions, not against theft and physical appropriation, but against publication in any form, is in reality not the principle of private property, but that of an inviolate personality."15 The equation of privacy with "inviolate personality," however, occasions an important ambiguity in the article: What does it mean to violate personality?

Warren and Brandeis offer two distinct lines of analysis, each pointing toward a different conception of privacy. The first suggests what may be called a "descriptive" concept of privacy. The Right to Privacy opens with a paean to the "eternal youth" of the common law, which initially offered protection only to the physical body, but has since grown to recognize "man's spiritual nature, . . . his feelings and his intellect." 16 What the "general right to privacy" ought now to safeguard, the article claims, are the "[t]houghts, emotions, and sensations" that comprise personality itself. ${ }^{17}$ Borrowing from Thomas Cooley's description of the law's extension to the physical body of "immunity from attacks and injuries," ${ }^{18}$ Warren and Brandeis conceptualize this protection of personality as "the right 'to be let alone." "19

Warren and Brandeis analyze the common law copyright cases by asking: "What is the thing which is protected?"20 The answer, at least according to one line of reasoning in the article, is personality understood as an amalgam of empirically ascertainable states. To violate this personality is to disturb it, to cause it "mental pain and distress." ${ }^{21}$ Just as the physical violation of the body can be avoided by surrounding the body with a buffer of unbreachable space, so the violation of personality can be prevented by surrounding the personality with a buffering space of "solitude and privacy"22 to insulate emotions and sensations from

15. Warren \& Brandeis, supra note 1 , at 205.

16. Id. at 193.

17. Id. at 195, 206.

18. T. Cooley, A Treatise on the Law of Torts 24 (1888).

19. Warren \& Brandeis, supra note 1 , at 195 (quoting T. CooleY, supra note 18 , at 29). Cooley writes: "The right to one's person may be said to be a right of complete immunity: to be let alone. The corresponding duty is, not to inflict an injury, and not, within such proximity as might render it successful, to attempt the infliction of an injury." T. COOLEY, supra note 18, at 29.

20. Warren \& Brandeis, supra note 1 , at 201.

21. Id. at 196.

22. Id. 
the world. ${ }^{23}$

It follows for Warren and Brandeis that the common law ought to secure "to each individual the right of determining, ordinarily, to what extent his thoughts, sentiments, and emotions shall be communicated to others," whether these attributes of personality are "expressed in writing, or in conduct, in conversation, in attitudes, or in facial expression." ${ }^{24}$ I call this concept of privacy "descriptive" because its application depends entirely upon ascertaining factual knowledge about the state of the world. The most thoughtful analysis of descriptive privacy is by Ruth Gavison, who suggests that it can be broken down into the "three independent components" of "secrecy, anonymity, and solitude."2s Privacy is lost "as others obtain information about an individual, pay attention to him, or gain access to him." gument is that these objectively measurable dimensions of privacy are so important that individuals ought legally to retain control over them.

There is, however, a distinct line of analysis in The Right to Privacy that points to a quite different conception of privacy, which I shall call "normative." If one looks closely at the article's description of the space that is supposed to buffer personality from the world, the language is less that of empirical distance than of moral characterization. Warren and Brandeis speak of the press "overstepping in every direction the obvious bounds of propriety and of decency";27 they speak of privacy as rooted in "the respect due to private life" and of the law only penalizing "the more flagrant breaches of decency and propriety";28 they conceptualize privacy as establishing a "pale of propriety" whose boundaries can only be fixed by taking "account of the varying circumstances of each case." 28

So conceived, privacy does not refer to an objective physical space of secrecy, solitude, or anonymity, but rather to the forms of respect that we owe to each other as members of a common community. Personality is violated when these forms of respect are transgressed. To speak of an invasion of privacy, therefore, is not

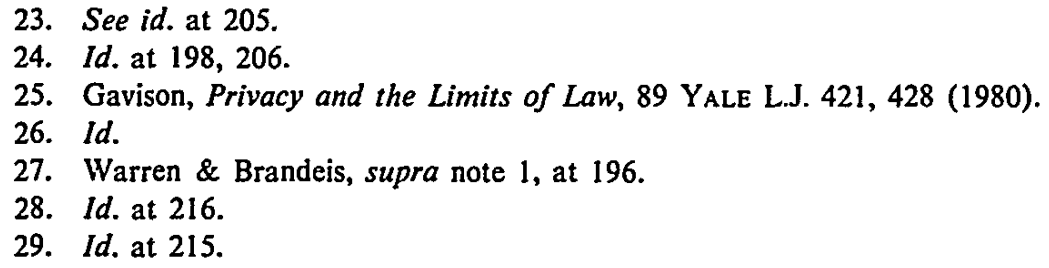


(merely) to describe factual propositions about the state of the world; it is rather to characterize the legitimacy of actions by exercising what Georg Simmel calls "moral tact." 30 Privacy in this sense is "normative" because it ultimately entails the articulation and application of social norms.

Infringements of normative privacy rupture socialized expectations of respect and so can impair "the mental peace and comfort of the individual and may produce suffering much more acute than that produced by mere bodily injury." 31 Hence by enforcing norms of propriety the law affords protection to personality, although its object is not the elimination of painful sensations per se. Moreover by enforcing norms of propriety the law also defines and conserves the community instantiated by those norms, ${ }^{32}$ a concern that Warren and Brandeis considered of deep significance. ${ }^{33}$ Indeed, nothing in The Right to Privacy is now quite so striking as the extraordinarily strict mugwump concept of community that the article attempts to enunciate and enforce. ${ }^{34}$

The concept of descriptive privacy is necessary for several purposes, including functional and cross-cultural analyses..$^{38} \mathrm{But}$ the great weakness of descriptive privacy is that it contains no account whatever of why its loss might cause damage to personality. ${ }^{36}$ Mere exposure, understood as the transmission of measurable bits of information, or mere proximity, understood as the loss of physical solitude, may or may not cause mental distress, de1950).

31. Pound, Interests of Personality, 28 Harv. L. Rev. 343, 363 (1915).

32. Post, The Social Foundations of Privacy: Community and Self in the Common Law Tort, 77 CALIF. L. REv. 957, 959-68, 976-78 (1989).

33. Warren \& Brandeis, supra note 1, at 196.

34. Barron, Warren and Brandeis, The Right to Privacy, 4 Harv. L. Rev. 193 (1890): Demystifying a Landmark Citation, 13 Suffolk U.L. Rev. 875, 914-18 (1979) ("Warren and Brandeis were ... struggling to defend a traditional, narrow, 'patrician' perception of what was 'news,' what was of public interest and therefore publishable.").

35. See Post, supra note 32, at 969-70.

36. There are, of course, functional accounts of why a certain degree of descriptive privacy might be necessary for a healthy personality. See, e.g., Gavison, supra note 25 , at 442-44. But these accounts do not purport to contend that descriptive privacy is necessary per se. Indeed Gavison begins her functional account with: the obvious [premise] that both perfect privacy and total loss of privacy are undesirable. Individuals must be in some intermediate state-a balance between privacy and interaction - in order to maintain human relations, develop their capacities and sensibilities, create and grow, and even to survive. Privacy thus cannot be said to be a value in the sense that the more people have of it, the better. Id. at 440 . 
pending upon the circumstances. ${ }^{37}$ Normative privacy, on the other hand, lends itself to a straightforward account of why a person socialized to certain forms of respect would experience harm when those forms of respect are disregarded. ${ }^{38}$ Despite this important difference, The Right to Privacy is pervasively equivocal as between normative and descriptive privacy.

As matters later developed, the intrusion ${ }^{38}$ and public disclosure ${ }^{40}$ branches of the privacy tort came to depend entirely upon normative rather than descriptive conceptions of privacy. ${ }^{41}$ It quickly became evident that these branches of the tort could be given coherent legal formulation only by reference to the normative judgments of the "reasonable person." ${ }^{42}$ But the tort of appropriation has remained somewhat apart, ambiguous like the Warren and Brandeis article as between descriptive and normative conceptions of privacy. ${ }^{43}$ The question I want to address is why this is so, and whether, to disclose the direction of my argument, it is connected to the concomitant fact that appropriation also remains of all the branches of the privacy tort uniquely undifferentiated from concepts of property.

37. Post, supra note 32, at 969-74.

38. Id. at 962-63; cf. Post, The Constitutional Concept of Public Discourse: Outrageous Opinion, Democratic Deliberation, and Hustler Magazine v. Falwell, 103 Harv. L. REv. 601, 616-24 (1990) (regarding intentional infliction of emotional distress).

39. See Restatement (SECOND) OF TORTS \& 652B (1976):

One who intentionally intrudes, physically or otherwise, upon the solitude or seclusion of another or his private affairs or concerns, is subject to liability to the other for invasion of his privacy, if the intrusion would be highly offensive to a reasonable person.

40. Id. § 652D:

One who gives publicity to a matter concerning the private life of another is subject to liability to the other for invasion of privacy, if the matter publicized is of a kind that

(a) would be highly offensive to a reasonable person, and

(b) is not of legitimate concern to the public.

41. See Post, supra note 32, at 959-74, 978-87.

42. See supra notes 39-40. The false light branch of the tort also invokes the reasonable person standard. See Restatement (SECOND) OF TORTS § 652E.

43. Compare Restatement OF TORTS $\S 867$ (1939) (applying a reasonable person standard) with RESTATEMENT (SECOND) OF TORTS § 652C (defining appropriation tort in terms of property rather than the reasonable person standard). Compare Bitsie v. Walston, 85 N.M. 65, 515 P.2d 659 (Ct. App. 1973) (liability requires finding of offensiveness to a reasonable person of ordinary sensibilities), and Reed v. Real Detective Pub. Co., 63 Ariz. 294, 162 P.2d 133 (1945) (applying reasonable person standard), with Canessa v. J.I. Kislak, Inc., 97 N.J. Super. 327, 357, 235 A.2d 62, 79 (1967) ("'ordinary sensibilities' test is irrelevant to . . . 'appropriation' case[s]"), and Flake v. Greensboro News Co., 212 N.C. 780, 195 S.E. 55 (1938) (propriety of injunctive relief for appropriation is determined without regard to offensiveness or ordinary sensibilities). 


\section{Common Law Copyright, Property, and Personality}

We are returned, therefore, to the central enterprise of The Right to Privacy, which is to argue that "legal doctrines relating to infractions of what is ordinarily termed the common-law right to intellectual and artistic property are, it is believed, but instances and applications of a general right to privacy . . ." ${ }^{44}$ At the time Warren and Brandeis were writing, statutory copyright consisted of legislative protection extended to literary and artistic works upon their publication. The common law, however, afforded protection to literary and artistic works before their publication. ${ }^{45}$ This protection was conceived as a property right, and it empowered authors and artists to prevent unauthorized publication of their unpublished works. Warren and Brandeis sought to conclude from this that the "common law secures to each individual the right of determining, ordinarily, to what extent his thoughts, sentiments, and emotions shall be communicated to others." ${ }^{46}$

What stood in the way of this conclusion was that common law copyright, as it was generally understood, extended its protection not to "thoughts, sentiments, and emotions," 47 but to specific literary or artistic work, whether in the form of manuscripts, letters, diaries, or engravings. Protection was extended to this work on the principle that "[a] production of mind is property in every essential sense in which a production of hands is the producer's property." 48 The entire structure of common law copyright was thus oriented toward the protection of "distinguishable evidence of intellectual effort." 49

This orientation served both to define the thing that would receive legal protection and to supply the justification for that protection. The "sole foundation" of common law copyright was "the right which every man has to the exclusive possession and control

44. Warren \& Brandeis, supra note 1, at 198.

45. See 2 P. Goldstein, Copyright: Principles, LaW and Practice \$§ 15.4-15.6 (1989); 1 M. Nimmer, Nimmer on Copyright $\S 2.02$ (1978 \& Supp. 1990); Strauss, Protection of Unpublished Works (1957), reprinted in Study No. 29, COPYRIGHT LaW Revision, Studies Prepared for the Subcommittee on Patents, Trademarks, and Copyrights of the Committee on the Judiciary, United States Senate, 86th Cong., 2d Sess. (1961).

46. Warren \& Brandeis, supra note 1, at 198.

47. Id.

48. Grigsby v. Breckinridge, $65 \mathrm{Ky}$. (2 Bush) 480, 485 (1867).

49. Pratt, The Warren and Brandeis Argument for a Right to Privacy, 1975 PuB. L. $161,174$. 
of the products of his own labor." ${ }^{\text {"so }}$ Because they desired to construct a right of privacy that extended protection to an entire inviolate personality and not just to its products, Warren and Brandeis believed that they were forced to dismantle the property law structure of common law copyright.

\section{A. The Argument from Authority}

The bulk of their effort to do this, when measured by length of argumentation, is not today of any great interest, for it rests upon a strained and historically sterile reading of a single decision, Prince Albert v. Strange. ${ }^{51}$ In that remarkable case, William Strange had somehow managed to obtain etchings that Queen Victoria and Prince Albert had executed for their own private amusement, and was threatening to exhibit them together with a "Descriptive Catalogue," evidently with the purpose "of being, in common language, 'bought off." "'52 Prince Albert sought an injunction prohibiting the exhibition and ordering the destruction of the Catalogue. The injunction was ultimately granted by Lord Chancellor Cottenham, who viewed the case as falling so clearly "within established principles, that the application of them is not attended with any difficulty." 53

One of these principles, not relevant here, was that the etchings were obtained through "a breach of trust, confidence, or contract" and that therefore their exhibition, together with the publication of the Catalogue, could be enjoined. ${ }^{54}$ Later decisions have in fact read Strange to rest on the principle that the publication of unpublished works obtained through breach of "a confidential relation" can be enjoined, as well as "any communication of their

50. Woolsey v. Judd, 11 How. Pr. 49, 57 (N.Y. Sup. Ct. 1855). Protection was most definitely not extended on the general ground of preventing the violation of important social norms:

A court of equity is not the general guardian of the morals of society. It has not an unlimited authority to enforce the performance or prevent the violation of every moral duty. It would be extravagant to say that it may restrain, by an injunction, the perpetration of every act which it may judge to be corrupt in its motives, or demoralizing, or dangerous in its tendency.

Id. at 54; see Gee v. Pritchard, 2 Swanst. 402, 426, 36 Eng. Rep. 670, 678 (1818).

51. 2 De G. \& Sm. 652, 64 Eng. Rep. 293 (V.C. 1848), affd, 1 Mac \& G. 25, 41 Eng. Rep. 1171 (Ch. 1849).

52. Id. at 688,64 Eng. Rep. at 308.

53. 1 Mac \& G. 25, 40, 41 Eng. Rep. 1171, 1177 (Ch. 1849).

54. Id. at 44, 41 Eng. Rep. at 1178-79. 
contents to third persons."

More relevant for Warren and Brandeis's argument was the principle that the etchings were the property of Prince Albert and Queen Victoria, and that the royal couple possessed, therefore, "the right to prevent the exhibition or publication of any copies of them ...."56 This principle formed the basis for much of the reasoning in the Strange opinion. The question posed by Warren and Brandeis was why the principle justified prohibiting Strange from publishing his Catalogue of the etchings. To this question Cottingham had a prosaic but defensible answer:

It being admitted that the Defendant could not publish a copy, that is an impression, of the etching, how in principle does a catalogue, list, or description differ? A copy or impression of the etching would only be a means of communicating knowledge and information of the original, and does not a list and description do the same? The means are different, but the object and effect are similar; for, in both, the object and effect is to make known to the public more or less of the unpublished work and composition of the author, which he is entitled to keep wholly for his private use and pleasure, and to withhold altogether, or so far as he may please, from the knowledge of others. ${ }^{.7}$

The point was that Strange's "Descriptive Catalogue" actually conveyed the content of the etchings, and so pro tanto could be enjoined as a publication of them.

In his opinion below, however, Vice Chancellor J. L. Knight Bruce had speculated in dicta that the publication of a mere list of the etchings could also have been enjoined:

Property in mechanical works or works of art, executed by a man for his own amusement, instruction or use, is allowed to subsist certainly, and may, before publication by him, be invaded, not merely by copying, but by description or by catalogue, as it appears to me. A catalogue of such works may in itself be valuable. It may also as effectually shew the bent and turn of the mind, the feelings and taste of the artist, especially if not professional, as a list of his papers. The portfolio or the studio may declare as much as the writing-table. A man may employ himself in private in a manner very harmless, but which, disclosed to society, may destroy the comfort of his life, or even

55. Philip v. Pennell, 2 Ch. 577, 586-87 (1907).

56. Prince Albert, 1 Mac \& G. at 43, 41 Eng. Rep. at 1178 .

57. Id. at 43,41 Eng. Rep. at 1178. 
his success in it. ${ }^{.8}$

This language was very helpful to Warren and Brandeis, for it began to move away from a narrow emphasis on the specific results of intellectual effort, and toward a general focus on personality itself. This shift pervaded Bruce's approach to the case. At another point in his opinion he argued that " $[\mathrm{b}] \mathrm{y}$ publishing of a man that he has written to particular persons, or on particular subjects, he may be exposed, not merely to sarcasm, he may be ruined," and that therefore Bruce hoped and believed that the law would enjoin the publication of "a mere list of . . manuscripts, without authority or consent."

Warren and Brandeis made the most out of Bruce's evident concern with protecting private activities. They properly observed that under the circumstances of Bruce's hypothetical an injunction against a mere list could not "rest upon the right to literary or artistic property in any exact sense,"

[I]t is difficult to perceive . . . why, if such a publication would be restrained when it threatened to expose the victim not merely to sarcasm, but to ruin, it should not equally be enjoined, if it threatened to embitter his life. . . If the fiction of property in a narrow sense must be preserved, it is still true that the end accomplished by the gossip-monger is attained by the use of that which is another's, the facts relating to his private life, which he has seen fit to keep private. . .

These considerations lead to the conclusion that the protection afforded to thoughts, sentiments, and emotions, expressed through the medium of writing or of the arts, so far as it consists in preventing publication, is merely an instance of the enforcement of the more general right of the individual to be let alone. ${ }^{61}$

The difficulty with this line of analysis, however, is that the more generous implications of Bruce's approach both badly misstated precedential authority and were in the end seriously beside the hard legal point of his decision. Professor Pratt has shown, for example, that "[n]ewspapers which reported the Prince Albert case included a list of the etchings; the decision did not prohibit the publication of a list, it prohibited the publication of a descrip-

58. 2 De G. \& Sm. at 696-97, 64 Eng. Rep. at 312.

59. Id. at 693-94, 64 Eng. Rep. at 311.

60. Warren \& Brandeis, supra note 1 , at 202.

61. Id. at 204-05. 
tion which, according to the Lord Chancellor, would have the same effect as publication of a copy." 62

Following Cottingham's reasoning, no English case has interpreted Strange in the manner advocated by Warren and Brandeis. ${ }^{63}$ And even Brandeis himself appears later to have abandoned any pretension that common law copyright could be given the interpretation he and Warren had advocated in their article. In his well-known dissent in International News Service v. Associated Press, ${ }^{64}$ he wrote that cases involving

the common-law right of the producer to prohibit copying . . . rest upon the ground that the common law recognizes such productions as property which, despite restricted communication, continues until there is a dedication to the public under the copyright statutes or otherwise. . . . At common law . . . intellectual productions are entitled to such protection only if there is underneath something evincing the mind of a creator or originator, however modest the requirement. The mere record of isolated happenings, whether in words or by photographs not involving artistic skill, are denied such protection.... At common law . . . the element in intellectual productions which secures such protection is not the knowledge, truths, ideas, or emotions which the composition expresses, but the form or sequence in which they are expressed; that is, "some new collocation of visible or audible points, - of lines, colors, sounds, or words." . . . An author's theories, suggestions, and speculations ... derive no such protection . . . ${ }^{85}$

\section{B. The Argument from Personality}

The argument from authority was important to Warren and Brandeis because they were concerned to cast the right to privacy as a mere extension of existing common law principles and so avoid the charge of "judicial legislation." importance today, and so their failure to establish precedential support is at most of historical interest. What is more significant to our own efforts to assess the significance of the revolution

62. Pratt, supra note 49 , at $172-73$ (footnote omitted).

63. The influence of Warren and Brandeis's misreading of Strange nevertheless persists in American legal scholarship. See, e.g., Newman, Copyright Law and the Protection of Privacy, 12 Colum.-VLA J.L. \& ARTS 459, 464 (1988).

64. 248 U.S. 215 (1918).

65. Id. at 253-55 (Brandeis, J., dissenting) (citations omitted).

66. Warren \& Brandeis, supra note 1 , at 213 n.1. 
wrought by The Right to Privacy is the analytic relationship of privacy to property. And on this issue Warren and Brandeis's discussion is considerably less developed. Their article does, however, contain the seeds of an important argument that deeply illuminates the nature of common law copyright.

The accepted rationale for common law copyright lay in the concept of "labor." ${ }^{\text {" }}$ Legal decisions explained the purpose of copyright as the protection of intellectual effort:

It is generally recognized that one has a right to the fruits of his labor. This is equally true, whether the work be muscular or mental or both combined. Property in literary productions, before publication and while they rest in manuscript, is as plain as property in the game of the hunter or in the grain of the husbandman. ${ }^{88}$

This explanation, of course, makes perfect sense in the context of the conscious creation of a literary work, where the labor involved is obvious. But the explanation is puzzling when applied to the composition of a casual letter or diary entry, which were also protected by common law copyright. ${ }^{68}$

With regard to such compositions, the accepted rationale for common law copyright began to falter. "The labor of composing letters for private and familiar correspondence may be trifling, or it may be severe, but it is none the less the result of an expenditure of thought and time." ${ }^{\prime \prime 0}$ This explanation prompted Warren and Brandeis to a penetrating inquiry. Why, they asked, is the machinery of property routinely wheeled out to protect the "trifling" labor involved in correspondence, when it is denied to the greater "expenditure of thought and time" necessitated by the living of life itself:

It may be urged that a distinction should be taken between the deliberate expression of thoughts and emotions in literary or artistic compositions and the casual and often involuntary expression given to them in the ordinary conduct of life. In other words, it may be contended that the protection afforded is

67. See generally E. Drone. A Treatise on the Law of Property in Intellectual Productions 1-53 (1879) (discussing the origins of literary property).

68. Baker v. Libbie, 210 Mass. 599, 604, 97 N.E. 109, 111 (1912).

69. Warren and Brandeis correctly note that the protection afforded by common law copyright to an unpublished writing is "entirely independent of its pecuniary value, its intrinsic merits, or of any intention to publish the same." Warren \& Brandeis, supra note 1, at 204.

70. Baker, 210 Mass. at 604,97 N.E. at 111. 
granted to the conscious products of labor, perhaps as an encouragement to effort. This contention, however plausible, has, in fact, little to recommend it. If the amount of labor involved be adopted as the test, we might well find that the effort to conduct one's self properly in business and in domestic relations had been far greater than that involved in painting a picture or writing a book; one would find that it was far easier to express lofty sentiments in a diary than in the conduct of a noble life. If the test of deliberateness of the act be adopted, much casual correspondence which is now accorded full protection would be excluded from the beneficent operation of existing rules. After the decisions denying the distinction attempted to be made between those literary productions which it was intended to publish and those which it was not, all considerations of the amount of labor involved, the degree of deliberation, the value of the product, and the intention of publishing must be abandoned, and no basis is discerned upon which the right to restrain publication and reproduction of such so-called literary and artistic works can be rested, except the right to privacy, as part of the more general right to the immunity of the person,-the right to one's personality. ${ }^{71}$

In this crucial passage Warren and Brandeis begin to uncover the disparity between the accepted "labor" justification for common law copyright and the actual shape of the law.

In fact when pressed upon the exact nature of the labor involved in intellectual production, the common law was apt to speak" instead of "originality" as the true grounds of "the title of the property. If a person claims to be the owner of an intellectual production, on the ground that it is the creation of his own mind, it is obvious that his title will fail when there is an entire absence of originality ...."72 And the common law was prepared to concede that originality was less a matter of intellectual effort than of expressing "the mind of a creator or originator," as Brandeis well knew. ${ }^{73}$ Hence Mr. Justice Erle in Jefferys $v$. Boosey ${ }^{74}$ noted:

The origin of property is in production. As to works of imagination and reasoning, if not of memory, the author may be said to

71. Warren \& Brandeis, supra note 1, at 206-07 (footnote omitted).

72. E. Drone, supra note 67 , at 110 . For an example of the persistence of this focus on originality, see Feist Publications, Inc. v. Rural Telephone Serv. Co., 111 S. Ct. 1282 (1991).

73. See International News Serv. v. Associated Press, 248 U.S. 215, 254 (1918) (Brandeis, J., dissenting).

74. 4 H.L. Cas. 814, 10 Eng. Rep. 681 (1854). 
create, and, in all departments of mind, new books are the product of the labour, skill, and capital of the author. The subject of property is the order of words in the author's composition; not the words themselves, they being analogous to the elements of matter, which are not appropriated unless combined, nor the ideas expressed by those words, they existing in the mind alone, which is not capable of appropriation. ...

$\cdots \cdot$

. . . [T] claim is not to ideas, but to the order of words, and ... this order has a marked identity and a permanent endurance. Not only are the words chosen by a superior mind peculiar to itself, but in ordinary life no two descriptions of the same fact will be in the same words . . . . The order of each man's words is as singular as his countenance, and although if two authors composed originally with the same order of words, each would have a property therein, still the probability of such an occurrence is less than that there should be two countenances that could not be discriminated. ${ }^{75}$

The common law did not protect ideas, even though ideas were obviously the result of intellectual labor. ${ }^{76}$ It instead protected the original expression of ideas. ${ }^{77}$ The concept of "labor" thus modulated into the concept of "creation," and the" sign of creation was the communication of "a marked identity." And it is for that reason that even casual letters were protected, "for they consist of the thoughts and language of the writer reduced to written characters, and show his style and his mode of constructing sentences, and his habits of composition." "78 But the logical conclusion of this reasoning, as Oliver Wendell Holmes understood with his usual clarity, was that the object of the law's solicitation was

75. Id. at $867,869,10$ Eng. Rep. at 702-03.

76. See, e.g., Moore v. Ford Motor Co., 28 F.2d 529, 536 (S.D.N.Y. 1928); Desny v. Wilder, 46 Cal. 2d 715, 731-33, 299 P.2d 257, 265-66 (1956); Haskins v. Ryan, 71 N.J. Eq. 575, 578-79, 64 A. 436, 437-38 (1906).

77. As the Supreme Court of the United States has said, in words addressed to statutory copyright, but which are equally applicable to common law copyright:

Unlike a patent, a copyright gives no exclusive right to the art disclosed; protection is given only to the expression of the idea-not the idea itself. . . The distinction is illustrated in Fred Fisher, Inc. v. Dillingham, 298 F. 145, 151, when the court speaks of two men, each a perfectionist, independently making maps of the same territory. Though the maps are identical, each may obtain the exclusive right to make copies of his own particular map, and yet neither will infringe the other's copyright. ... The copyright protects originality rather than novelty or invention-conferring only "the sole right of multiplying copies." Mazer v. Stein, 347 U.S. 201, 217-18 (1954).

78. Folsom v. Marsh, 9 F. Cas. 342, 346 (C.C.D. Mass. 1841) (No. 4,901). 
nothing less than "personality" itself: "The copy is the personal reaction of an individual upon nature. Personality always contains something unique. It expresses its singularity even in handwriting, and a very modest grade of art has in it something irreducible, which is one man's alone. That something he may copyright ....."ro

Warren and Brandeis were thus quite right to move from labor to "the right to one's personality," for in a variety of contexts common law copyright was at root concerned to protect "the objectification of a personality." ${ }^{\text {"80 }}$ And in the years after The Right to Privacy, as Warren and Brandeis might have predicted, common law copyright would even contemplate safeguarding objectifications of personality that were not fixed in the "tangible form" of letters or etchings; but were instead merely manifested during the flow of private "conversational speech." 11

\section{Privacy, Property, and Personality}

It does not follow, however, that Warren and Brandeis were correct that common law copyright had all along been unconsciously protecting privacy. The Right to Privacy brilliantly demonstrates that the language of property is not irresistibly thrust upon common law copyright by the object of its protection. Despite the rhetoric of common law judges and commentators, Warren and Brandeis understood that there was nothing in the intrinsic nature of letters or etchings that made them property. If anything the causal arrow was reversed: letters were conceptualized as property because the common law chose to objectify the aspects of personality they embodied.

Warren and Brandeis evidently believed that once common law copyright was forced to recognize its roots in personality, it would necessarily shift its foundation from property to privacy. But this was a non sequitur, caused by the failure fully to appreciate what might be called the independence of legal characterization. The law can commodify personality as property, or it can

79. Bleistein v. Donaldson Lithographing Co., 188 U.S. 239, 250 (1903). The relationship of Holmes's formulation in Bleistein to that of Warren and Brandeis in The Right to Privacy has not gone unnoticed. See B. KAPLAN, AN UNHURRIEd VIEW OF Copyright 35 n.93 (1967).

80. Rose, The Author as Proprietor: Donaldson v. Becket and the Genealogy of Modern Authorship, 23 Representations 51, 75 (1983).

81. Estate of Hemingway v. Random House, Inc., 23 N.Y.2d 341, 345-48, 244 N.E.2d 250, 253-55, 296 N.Y.S.2d 771, 776-78 (1968). 
instead protect emotional integrity through tort actions analogous to those of defamation: The choice depends upon reasons of policy, not upon the intrinsic nature of personality itself. The fundamental issue, therefore, is not whether the law ought to protect personality, but rather how the law ought to conceptualize personality for purposes of legal protection.

\section{A. Property Rights and Personal Rights}

There has been much fine work recently on the "disintegration of property." 82 Yet in attempting to extricate privacy from property, Warren and Brandeis were working within well-defined legal traditions that persist to this day. They were advocating that privacy be embodied within a regime of personal rather than property rights. What this meant can best be made visible by contrasting the legal characteristics of common law copyright with those of the kind of personal tort action that Warren and Brandeis were proposing.

The property right protected by common law copyright, reflecting its origins in the order of the market, was clearly alienable. It could be assigned, sold, or otherwise transferred. ${ }^{83}$ Personal rights embracing "torts to the person or character where the injury and damage are confined to the body and the feelings," on the other hand, were not assignable. ${ }^{84}$ Warren and Brandeis could therefore anticipate that their proposed right of privacy would be nonalienable, attached to specific injured individuals. That is in fact the current state of the law. ${ }^{85}$ "It is well settled that the right of privacy is purely a personal one; it cannot be asserted by anyone other than the person whose privacy has been invaded, that is, plaintiff must plead and prove that his privacy has been invaded."86 Personal tort actions for privacy cannot ordinarily be

82. See, e.g., Grey, The Disintegration of Property, in Property, Nomos XXII 69, $69-85(1980)$.

83. E. DRONE, supra note 67 , at 104-06.

84. 3 J. Pomeroy, A Treatise on Equity Jurisprudence § 1275 (3d ed. 1905); see Ware v. Brown, 29 F. Cas. 220 (C.C.S.D. Ohio 1869) (No. 17,170); J. TownSHEND, A Treatise on the Wrongs Called Slander and Libel $\$ 299$ (4th ed. 1890).

85. See, e.g., K.L. Scheppele, Legal Secrets: Equality and Efficiency in the COMMON LAW 187 (1988).

86. Lugosi v. Universal Pictures, 25 Cal. 3d 813, 821, 603 P.2d 425, 430, 160 Cal. Rptr. 323, 328 (1979) (emphasis in original) (quoting, with insignificant error, Hendrickson v. California Newspapers, Inc., 48 Cal. App. 3d 59, 62, 121 Cal. Rptr. 429, 431 (1975)). Thus privacy rights may be waived, but not sold or transferred. 
sold, assigned, or otherwise transferred to others. ${ }^{87}$

Just as the property right protected by common law copyright could be alienated from its owner, so could it also survive its owner's death. ${ }^{88}$ Common law copyright was thought to endure forever; ${ }^{8 \theta}$ it could be devised by will or descend through intestate succession. ${ }^{90}$ Conversely, the personal privacy right advocated by Warren and Brandeis could be expected to follow the general rule "actio personalis moritur cum persona, or the right of action for tort is put an end to by the death of either party."11 To this day, privacy actions, in the absence of statutory intervention, "can be maintained only by a living individual whose privacy is invaded," and are therefore neither devisable nor descendible. ${ }^{92}$ A personal right to privacy "dies with the person."

Warren and Brandeis were undoubtedly aware of other important technical differences that followed from the legal characterization of their proposed privacy right. ${ }^{94}$ But the distinction

87. Restatement (Second) of ToRTs § 652I comment a (1976); Nimmer, The Right of Publicity, 19 LAw \& CONTEMP. ProBs. 203, 209 (1954). Reflecting the ambiguous state of the appropriation tort, midway between a personal and a property right, the second Restatement remarks that "the only exception" to the "rule" against the assignability of an action for invasion of privacy "involves the appropriation to the defendant's own use of another's name or likeness." RESTATEMENT (SECOND) OF TORTS § 652I comment a.

88. This was connected to the broader principle that "the test of survivorship of a cause of action is its assignability, and conversely, the test of assignability is survivorship-that is to say that they are always concomitant." Ingersoll v. Gourley, 72 Wash. 462, 466, 130 P. 743, 745 (1913); see 3 J. Pomeroy, supra note 84, at $§ 1275$.

89. E. Drone, supra note 67 , at 100 ; Newman, supra note 63 , at 463 ; Note, Copyright and Privacy Protection of Unpublished Works-The Author's Dilemma, 13 Colum. J.L. \& Soc. Props. 351, 359 (1977). Considerations of policy, however, were understood to warrant temporal limitations on property rights, and in fact were thought to justify the restricted duration of statutory copyright protections. Hesse, Enlightenment Epistemology and the Laws of Authorship in Revolutionary France, 1777-1793, 30 REPRESENTATIONS 110, 114-29 (1990); Note, supra at 367-69; cf. CAL. CIv. Code $§ 990(g)$ (West Supp. 1991) (limiting time for bringing suit for unauthorized use of a deceased personality's name or likeness to 50 years after the personality's death).

90. Note, Personal Letters: In Need of a Law of their Own, 44 IowA L. REv. 705, 710 (1959). $\S 299$.

91. F. Pollock. The LAW of TORTS 40 (1887); see J. Townshend, supra note 84,

92. Restatement (SECOND) OF TORTS § 6521 (1976); see Bluer, California Extends The Right of Publicity to Heirs: A Shift from Privacy to Property and Copyright Principles, 7 CoMm/ENT L.J. 575, 578 (1984); Gordon, supra note 2, at 612-13.

93. Hendrickson v. California Newspapers, Inc., 48 Cal. App. 3d 59, 62, 121 Cal. Rptr. 429, 431 (1975); see Reeves v. United Artists, 572 F. Supp. 1231 (N.D. Ohio 1983), aff'd, 765 F.2d 79 (6th Cir. 1985); Price v. Hal Roach Studios, Inc., 400 F. Supp. 836, 844 (S.D.N.Y. 1975).

94. For example, property rights clearly could be protected by injunction, and hence 
they were most concerned to press involved the question of damages. Damages available to a plaintiff for invasions of personality, conceptualized through the lens of the property right of common law copyright, were measured by market tests of unjust enrichment or lost profits. ${ }^{95}$ By reconceptualizing personality in terms of emotional integrity, Warren and Brandeis desired to make damages available instead for distress and anguish. They thus advocated that damages be seen as compensation for "the value of mental suffering." ${ }^{\text {Bg }}$ At the time they were writing, the common

injunctive relief was, and remains, a standard remedy for infringement of common law copyright. Salinger v. Random House, Inc., 811 F.2d 90, 96 (2d Cir. 1987); E. DRONE, supra note 67, at 107; 2 P. GoLDSTEIN, supra note 45, \$§ 11.0-11.2; 1 M. NIMMER, supra note 45 , at $\$ 14.06$; $c f$. Newman, supra note 63 , at 464 . It was considerably less certain whether injunctive relief would be available to protect the kind of personal privacy right advocated by Warren and Brandeis. Id. Warren and Brandeis evince uncertainty on this point, noting that an injunction might be available "in perhaps a very limited class of cases." Warren \& Brandeis, supra note 1, at 219. In a footnote, Warren and Brandeis cite two authors, both of whom remark on the unsettled state of the law, but both of whom nevertheless conclude that the majority rule is that injunctions are "limited to the protection of property rights" and that "courts of equity would not restrain the publications of libels or works of a libelous nature." $2 \mathrm{~J}$. HiGH, A TREATISE ON THE LAW OF INJUNCTIONS $\S 1015$ (4th ed. 1905); see also J. TownSHEND, supra note 83, at $\$ 417$ a. For other common law differences between personal and property rights, see Canessa v. J.I. Kislak, Inc., 97 N.J. Super. 327, 235 A.2d 62 (1967) (differences in statute of limitations); Ettore v. Philco Television Broadcasting Corp., 229 F.2d 481, 489 (3d Cir. 1956) (differences with respect to choice of law).

An important contemporary difference between conceptualizing privacy as a personal rather than as a property right concerns constitutional law. It is fair to say that the Supreme Court's interpretation of the first amendment has been hostile to restrictions on speech that arise from protecting the personal privacy of the person. See, e.g., Florida Star v. B.J.F., 491 U.S. 524 (1989); Cox Broadcasting Corp. v. Cohn, 420 U.S. 469 (1975); Time, Inc. v. Hill, 385 U.S. 374 (1967). But see Frisby v. Schultz, 487 U.S. 474 (1988). But the Court has been considerably more sympathetic to restrictions on speech that are justified in terms of the protection of a personality that has been conceptualized as property. See, e.g., Harper \& Row, Publishers, Inc. v. Nation Enters., 471 U.S. 539 (1985); Zacchini v. Scripps-Howard Broadcasting Co., 433 U.S. 562, 573-79 (1977); cf. International News Serv. v. Associated Press, 248 U.S. 215 (1918). This difference also obtains in the area of defamation. See Post, The Social Foundations of Defamation Law: Reputation and the Constitution, 74 CALIF. L. REv. 691, 726-39 (1986). So, for example, the routine injunction against communication that would ordinarily be regarded as a highly disfavored prior restraint is routinely tolerated when applied to speech that has been commodified as property. See In re Capital Cities/ABC Inc., 918 F.2d 140 (11th Cir. 1990); New Era Publications Int'l v. Henry Holt \& Co., 873 F.2d 576, 583-84 (2d Cir. 1990); In re Providence Journal Co., 820 F.2d 1342, 1345-46 (Ist Cir. 1986). This constitutional disparity vas even noticeable at the time of Warren and Brandeis. See J. TownsHend, supra note 84 , at $\$ 417$.

95. E. DRONE, supra note 67 , at $107,114-15,486,535$.

96. Warren \& Brandeis, supra note 1, at 213 . For a description of other social functions served by the remedy of damages in the context of the personal tort, see Post, supra note 32 , at $964-68$. 
law, although generally ambivalent or even hostile to such damages, ${ }^{97}$ was nevertheless willing to award them in those tortious situations like assault or false imprisonment where the dignity or honor of the personality was believed to be directly at stake. ${ }^{98}$ Warren and Brandeis's achievement in making such damages the centerpiece for the new privacy tort ${ }^{89}$ essentially depended upon their success in demonstrating that privacy was necessary for the integrity of personality.

The fundamental legal reconceptualization involved in the shift from the property right of common law copyright to the personal right of privacy is dramatically evident in the recent emergence of the tort dubbed by Jerome Frank in 1953 as the "right of publicity." ${ }^{100}$ Growing out of the appropriation tort, ${ }^{101}$ or, in the eyes of some courts, substituting for the appropriation tort, ${ }^{102}$ the right of publicity was designed as a property right that would safeguard the goodwill created by celebrities in their public persona. ${ }^{103}$ The obvious value of these persona, as well as the apparent labor involved in their establishment, led courts to devise a property right that would enable a celebrity to control "the commercial value in his identity."104 "The distinctive aspect of the common law right of publicity is that it recognizes the commercial value of the picture or representation of a prominent person or performer, and protects his proprietary interest in the profitability

97. See, e.g., Chapman v. Western Union Tel. Co., 88 Ga. 763, 15 S.E. 901 (1892) (mental distress damages allowable as an item of damages but cannot be the sole item of damages); J. DeERING. THE LAW OF NeGLigence § 416 (1886) ("[M]ere mental anxiety . . . unaccompanied by personal injury is not the subject of damages.").

98. See Stewart v. Maddox, 63 Ind. 51, 58 (1878); Hewellette v. George, 68 Miss. $703,710,9$ So. 885,887 (1891).

99. See Cabaniss v. Hipsley, 114 Ga. App. 367, 378, 151 S.E.2d 496, 504 (1966); Gordon, supra note 2, at 610-11; Nimmer, supra note 87, at 216.

100. Haelan Laboratories, Inc. v. Topps Chewing Gum, Inc., 202 F.2d 866, 868 (2d Cir. 1953).

101. See Tennessee ex. rel. Elvis Presley Int'l Memorial Fund v. Crowell, 733 S.W.2d 89, 95 (Tenn. App. 1987).

102. Carson v. Here's Johnny Portable Toilets, Inc., 698 F.2d 831, 834 (6th Cir. 1983); Factors Etc., Inc. v. Pro Arts, Inc., 579 F.2d 215, 220 (2d Cir. 1978).

103. Carson, 698 F.2d at 834 ("The right of publicity has developed to protect the commercial interest of celebrities in their identities.").

104. Lugosi v. Universal Pictures, 25 Cal. 3d 813, 839, 603 P.2d 425, 44l, 160 Cal. Rptr. 323, 339 (Cal. 1979) (Bird, C.J., dissenting); see Uhlaender v. Henricksen, 316 F. Supp. 1277, 1282 (D. Minn. 1970) ("It is this court's view that a celebrity has a legitimate proprietary interest in his public personality."); Bloom, Preventing the Misappropriation of Identity: Beyond the "Right of Publicity" 13 COMM/ENT L.J. 489, 491 (1991). 
of his public reputation or 'persona." "105

The process of distinguishing publicity from privacy rights was protracted and confused, ${ }^{106}$ but in the end the right of publicity has generally assumed the very characteristics of common law copyright from which Warren and Brandeis sought to differentiate the personal right of privacy. Actions to enforce rights of publicity are freely transferrable and alienable, ${ }^{107}$ and potentially devisable by will or descendible through intestate succession. ${ }^{108}$ Moreover the "key feature distinguishing the Right of Publicity" from the personal right to privacy is the "measure of damage," which for the former "focuses upon the commercial injury to the plaintiff" instead of upon indignity and mental distress. ${ }^{109}$ "[T] he right of publicity," in short, "does not differ in kind from copyright."110

\section{B. Privacy and Property}

Having acquired some appreciation of the actual operational significance of Warren and Brandeis's argument, we are now in a position to inquire why they were concerned to embody personality within a regime of personal rather than property rights. What exactly is at stake in the distinction between privacy and property?

At the most general level, the property created by common law copyright and the right to publicity transforms personality into a thing or an object ${ }^{111}$ whose value is to be determined by

105. Ali v. Playgirl, Inc., 447 F. Supp. 723, 728 (S.D.N.Y. 1978); see also Midler v. Ford Motor Co., 849 F.2d 460, 463 (9th Cir. 1988).

106. See generally J. McCarthy, The Rights of Publicity and Privacy (1987) (detailing the history of the distinction between the rights of publicity and privacy).

107. Id. § $10.3[\mathrm{~B}][1]-[2]$.

108. Price v. Hal Roach Studios, Inc., 400 F. Supp. 836, 844 (S.D.N.Y. 1975); J. MCCARTHY, supra note $106, \S \S 9.2-9.5$. Rights of publicity will also be protected by injunction. See, e.g., Factors Etc., Inc. v. Pro Arts, Inc., 579 F.2d 215, 222 (2d Cir. 1978); J. MCCARTHY, supra note 106, $\$ 11.6$. Moreover, the right of publicity is clearly viewed by the Supreme Court as more compatible with first amendment principles than privacy rights based upon nonproprietary characterizations of personality. See Zacchini v. Scripps-Howard Broadcasting Co., 433 U.S. 562, 573 (1977). The Court views the state's interest in the protection of the right to publicity as "analogous to the goals of patent and copyright law, focusing on the right of the individual to reap the reward of his endeavors and having little to do with protecting feelings or reputation." Id.

109. J. MCCARTHY, supra note $106, \S 11.8$.

110. Baltimore Orioles v. Major League Baseball Players Ass'n, 805 F.2d 663, 679 (7th Cir. 1986).

111. Waldron, What is Private Property?, 5 Oxford J. Legal Stud. 313, 327 (1985). 
reference to the institution of the market. Hence personality is commodified and becomes "something in the outside world, separate from oneself." ${ }^{112}$ For this reason, commodified personality can endure long beyond the living self of the individual who creates it, and it can also be owned and used by persons other than its creator. The self of the actual "creator or originator"113 of commodified personality is merely of marginal consideration, pertinent only to the achievement of the underlying legal policy of the "encouragement of individual effort by personal gain.".114 And because the law must accurately ascertain the boundaries of the thing exchanged among persons, commodified personality must itself be legally apprehended in terms capable of objective measurement. So, for example, common law copyright locates commodified personality in the physical "order of words,"118 a formulation compatible with requirements of descriptive privacy.

The personal right of privacy advocated by Warren and Brandeis, on the other hand, attaches personality firmly to the actual identity of a living individual. ${ }^{116}$ The right cannot be transferred; it is temporally bound to the life of a particular person. The purpose of the right is to facilitate the flourishing of that life, and the right therefore presupposes both a normative theory of human personality and an account of the relationship between that theory and the exercise of legal rights. ${ }^{112}$ This explains the dependence of the personal right of privacy upon normative rather than descriptive privacy, for only the former meets these prerequisites. $^{118}$

This dependence means that the personal right of privacy, like normative privacy, conceives the identities of particular per-

112. Radin, Property and Personhood, 34 Stan. L. Rev. 957, 966 (1982).

113. International News Serv. v. Associated Press, 248 U.S. 215, 254 (1918) (Brandeis, J., dissenting).

114. Mazer v. Stein, 347 U.S. 201, 219 (1953); see Zacchini v. Scripps-Howard Broadcasting Co., 433 U.S. 562, 573 (1976).

115. Jefferys v. Boosey, 4 H.L. Cas. 814, 869, 10 Eng. Rep. 681, 703 (1854).

116. It is no accident that Warren and Brandeis were writing at a time when American popular culture was coming to stress the idea of "personality" as "self-realization," embodying "the unique qualities of the individual." W. Susman. Culture as History 281 (1984). For an illuminating discussion of antebellum concepts of personality, see R. RABInowitz. The Spiritual Self in Everyday life: The Transformation of Personal Religious Experience in Nineteenth-Century New England 153-216 (1989).

117. See Post, supra note 32, at 964-68, 985-86 (discussing the relationship between the normative theory of human identity presupposed by the privacy tort and damages for indignity and mental distress).

118. See supra text accompanying notes $30-38$. 
sons as dependent upon the observance of social norms of respect. The function of the law is to uphold those norms. In contrast the commodified personality recognized by common law copyright and the right of publicity is not conceptualized as constitutive of the identities of particular persons, but as detachable from them. Commodified personality is "separate from the person and possessed by the person," from which vantage point the person recedes into an abstract and undifferentiated capacity to exercise "individual effort" to generate other and distinct commodifiable personalities. ${ }^{119}$ The function of the law is to sustain that capacity.

At issue in the distinction between privacy and property, therefore, is the legal conception of the person. The question is whether the law ought to construct its doctrine on the presupposition that identity is essentially embedded within and dependent upon particular social arrangements, or rather on the presupposition that identity most importantly resides in the capacity to create itself anew.

Of course any reasonably sophisticated sociological or psychological account of the self would acknowledge the existence and necessity of both these aspects of identity-embeddedness and independence. Personality can so effortlessly be legally embodied by either property or privacy rights precisely because it embraces

119. Radin, Market-Inalienability, 100 HARV. L. REv. 1849, 1897 (1987). This distinction helps to explain why first amendment doctrine regards the enforcement of personal privacy rights with special hostility, for such rights necessarily entail legal protection for a particular vision of community life, which is inconsistent with the purpose of public discourse to serve as a neutral "marketplace of communities." Post, supra note 38, at 632 . The inexhaustible capacity for regeneration presupposed by property rights, on the other hand, is not theoretically incompatible with the premises of public discourse, and is in fact roughly homologous to the individualism and "radical negativity" that characterizes the constitutional concept of that discourse. See id. at 626-44; Post, supra note 94, at 716. In particular circumstances, however, the operation of property rights may seriously interfere with the practical functioning of public discourse. See, e.g., Rogers v. Grimaldi, 695 F. Supp. 112, 121 (S.D.N.Y. 1988), aff'd, 875 F.2d 994 (2d Cir. 1989); Hicks v. Casablanca Records, 464 F. Supp. 426 (S.D.N.Y. 1978); Guglielmi v. Spelling-Goldberg Prods., 25 Cal. 3d 860, 603 P.2d 454, 160 Cal. Rptr. 352 (1979) (Bird, C.J., concurring); Paulsen v. Personality Posters, Inc., 59 Misc. 2d 444, 299 N.Y.S.2d 501 (Sup. Ct. 1968); Bloom, supra note 104 , at 528 .

I have no particularly cogent explanation as to why property rights, as distinguished from personal rights, routinely receive injunctive protection. I would only observe that restraining equitable enforcement of personal rights might have served the same policy as Fox's Libel Act, 32 Geo. 3, ch. 660 (1792), which ensured that juries, as distinguished from the King's judges, would be given the power to interpret community norms. For a discussion of Fox's Libel Act, see Z. Chafee, Free Speech in the United States 504-06 (1941), and T. Emerson, The System of Freedom of Expression 99 (1970). 
both these aspects. The question, therefore, is not which aspect of identity ought to be encouraged and which suppressed; it is rather the circumstances under which the law ought to lend its weight to one aspect of the self or the other. This conclusion may seem bland, but it will, I hope, help to illuminate what is at stake in some of the uncertainties that have unceasingly plagued the tort of appropriation.

\section{THE TORT OF Appropriation}

The Restatement (Second) of Torts defines the tort of appropriation in the following way:

One who appropriates to his own use or benefit the name or likeness of another is subject to liability to the other for invasion of his privacy. ${ }^{120}$

The definition appears to evoke descriptive rather than normative privacy, for a plaintiff's case can be established merely by proving facts about the state of the world. The plaintiff can recover damages for mental distress if his or her name or likeness has been "appropriated" to a defendant's own "use or benefit." But if we ask why this should be so, we immediately run into ambiguities.

\section{A. The Present Condition of the Tort}

There are two possible explanations for the present shape of the tort. The first, advanced by the late Edward Bloustein, is that "the commercialization of personality" is a "personal affront" that is "demeaning to human dignity." 121 Because appropriation intrinsically causes "mortification, humiliation and degradation,"122 plaintiffs ought to have personal privacy rights enabling them to sue for mental distress.

This explanation of the tort has a long pedigree and was in fact the rationale of Pavesich $v$. New England Life Insurance Co., ${ }^{123}$ which is generally acknowledged to be the first major decision recognizing the privacy tort advocated by Warren and Brandeis. ${ }^{124}$ The plaintiff in Pavesich, a private individual, sued an in-

120. Restatement (SeCond) of Torts § 652C (1976).

121. Bloustein, Privacy as an Aspect of Human Dignity: An Answer to Dean Prosser, 39 N.Y.U. L. REv. 962, 987 (1964).

122. Id.

123. 122 Ga. 190 , 50 S.E. 68 (1905).

124. The author of the Pavesich opinion, Judge Andrew Jackson Cobb, sent a copy of the decision to Brandeis, along with "very kind expressions." I L. BRANDEIS. THE LET- 
surance company for the unauthorized use of his picture in an advertisement for life insurance. The Georgia Supreme Court ruled that the defendant had violated the plaintiff's right to privacy:

The right of privacy has its foundation in the instincts of nature. . . . Each individual as [sic] instinctively resents any encroachment by the public upon his rights which are of a private nature ....

$\cdots$

It therefore follows . . . that a violation of the right of privacy is a direct invasion of a legal right of the individual. It is a tort, and it is not necessary that special damages should have accrued from its violation in order to entitle the aggrieved party to recover. ...

...

... There is in the publication of one's picture for advertising purposes not the slightest semblance of an expression of an idea, a thought, or an opinion .... The knowledge that one's features and form are being used for such a purpose, and displayed in such places as such advertisements are often liable to be found, brings . . . the individual of ordinary sensibility, to a realization that his liberty has been taken away from him; and, as long as the advertiser uses him for these purposes, he cannot be otherwise than conscious of the fact that he is for the time being under the control of another, that he is no longer free, and that he is in reality a slave, without hope of freedom, held to service by a merciless master; and if a man of true instincts, or even of ordinary sensibilities, no one can be more conscious of his enthrallment than he is. ${ }^{125}$

The passage plainly evokes normative privacy. It conceives commercial appropriation of a person's image as violative of essential norms of respect and hence as destructive of personality.

The difficulty with this explanation of the appropriation tort, however, is that the elements of the tort are phrased in terms of descriptive privacy, which serves as a rather poor proxy for normative concerns. There are circumstances in which a defendant's appropriation of an image for "his own use or benefit" would not be an affront, as for example in a Cartier-Bresson candid photo-

TERS OF Louis D. Brandeis 303-04 (M. Urofsky \& D. Levy eds. 1971). Brandeis said of the opinion that he was "pleased . . . to find that the right to Privacy is at last finding judicial recognition." Id. at 306.

125. Pavesich, $112 \mathrm{Ga}$. at 194, 201-02, 219-20, 50 S.E. at $69,73,80$. 
graph or a news photographer's rendition of a significant happening. Sometimes the use of a plaintiff's image is degrading not because it has been appropriated to a defendant's benefit, but rather because of the specific way in which it has been used. For example in Bitsie v. Walston ${ }^{128}$ the parents of a Navajo child consented to her being photographed, but objected when the photograph was displayed on a note card sold to benefit the Cerebral Palsy Fund. They did not find demeaning the appropriation of the child's image, but rather experienced its association with disease as a devastating harbinger of "bad luck."127

Sometimes, moreover, even the unauthorized commercial use of another's image could not reasonably be deemed to affront human dignity. In Canessa v. J.I. Kislak, Inc., ${ }^{128}$ for example, a family with eight children could not find an apartment or house to rent. In frustration they ran an advertisement in the "Lost and Found" section of the local newspaper. A local real estate firm answered the ad and assisted the family in purchasing a house. The local paper published a human interest story on the circumstances, which included a posed picture of the family. The real estate firm reprinted the article, stamped it with their "commercial trademark," and distributed it "without doubt for advertising purposes in advancement of . . . commercial interests." ${ }^{129} \mathrm{Al}-$ though the simple dissemination of the newspaper article was not itself actionable, ${ }^{130}$ the court concluded that by converting the article into an advertisement the real estate firm had committed the tort of appropriation.

This conclusion cannot be sustained under Bloustein's analysis of the tort, for it would seem almost incomprehensible to brand the circulation of an embossed newspaper article (itself quite legitimate) as a "mortification, humiliation and degradation." It is no surprise, therefore, that the court in Canessa concluded that if "advertisement exploitation" were established, it is "irrelevant" whether the use of the plaintiffs' image would deeply offend a person of "ordinary sensibilities." 131

In reaching this conclusion, Canessa points toward a second

126. 85 N.M. 655,515 P.2d 659 (Ct. App. 1973).

127. Id. at 658,515 P.2d at 662 .

128. 97 N.J. Super. 327, 235 A.2d 62 (1967).

129. Id. at 332,235 A.2d at 62 .

130. See Bisbee v. John C. Conover Agency, 186 N.J. Super. 335, 452 A.2d 689 (Ct. App. 1982).

131. 97 N.J. Super. at $356-58,235$ A.2d at $78-79$. 
possible explanation of the appropriation tort. Canessa defines appropriation as "an action for invasion of . . . 'property' rights and not one for "injury to the person." "132 It cites in support of this position Munden $v$. Harris, ${ }^{133}$ a very early case that interpreted appropriation as sounding in property:

One may have peculiarity of appearance, and if it is to be made a matter of merchandise, why should it not be for his benefit? It is a right which he may wish to exercise for his own profit and why may he not restrain another who is using it for gain? If there is value in it, sufficient to excite the cupidity of another, why is it not the property of him who gives it the value and from whom the value springs?

We therefore conclude that one has an exclusive right to his picture, on the score of its being a property right of material profit. ${ }^{134}$

If a casual letter can receive protection as property because it is an original reflection of its author's personality, "as singular as his countenance,"135 so the unauthorized reproduction of a person's image can similarly be likened "to the violation "of a sort of natural copyright possessed by every person of his or her own features." "136 If copyright can extend protection to the particular "order of words in the author's composition,"137 so appropriation can safeguard the particular "singularities," "lines," and "features" that fix and characterize a plaintiff's unique face. ${ }^{138}$ Understood in this way, the tort properly depends upon descriptive privacy, which delineates the measurable boundaries of the "thing"

132. Id. at $352,235 \mathrm{~A} .2 \mathrm{~d}$ at 76 .

133. 153 Mo. App. 652, 134 S.W. 1076 (1910).

134. Id. at $659-60,134 \mathrm{~S} . \mathrm{W}$. at 1078-79.

135. Jefferys v. Boosey, 4 H.L. Cas. 814, 869, 10 Eng. Rep. 681, 703 (1854).

136. Continental Optical Co. v. Reed, 119 Ind. App. 643, 649, 86 N.E.2d 306, 309 (1949). This same equation of personality and image appears in F. HARGRAVE, ARGUMENT in Defence of Literary Property (1774):

A strong resemblance of stile, of sentiment, of plan and disposition, will be frequently found; but there is such an infinite variety in the modes of thinking and writing, as well in the extent and connection of ideas, as in the use and arrangement of words, that a literary work really original, like the human face, will always have some singularities, some lines, some features, to characterize it, and to fix and establish its identity....

Id. at 7 , quoted in Rose, supra note 80 , at 72 .

137. Jefferys, 4 H.L. Cas. at 867, 10 Eng. Rep. at 702.

138. F. HARGRAVE, supra note 136 , at 7. 
that has become property. ${ }^{139}$

Although this account of the appropriation tort preserves its incorporation of descriptive privacy, it does so at the price of undermining the tort's authorization of damages for indignity and mental distress. If appropriation sounds in property, then the object of its protection is the "value" of the image or name that is, in effect, copyrighted. An allegation of copyright infringement would not support an award of general damages for pain or suffering, ${ }^{140}$ and neither ought an allegation of the infringement of an essentially "common law copyright" of one's image or name. ${ }^{141}$ Warren and Brandeis understood this quite clearly, which is why they sought to disengage privacy from property. ${ }^{142} \mathrm{~A}$ decision like Canessa that justifies liability in terms of the protection of property, ${ }^{143}$ and yet that authorizes general damages for pain and suffering even in the absence of any ascertainable harm to that property, thus runs a serious risk of internal incoherence, of blurring the design and purposes of the law.

\section{B. The Future of the Tort}

Our dilemma, then, is this: The descriptive privacy employed by the second Restatement's definition of appropriation is consistent with a property conception of the tort, but incompatible with a remedial focus on indignity and mental distress. Such a remedial focus must depend instead for its justification upon normative privacy. But normative privacy is inconsistent both with the elements of the tort set forth in the second Restatement and with the view that the tort creates a property interest. The situation is fur-

139. Thus copyright law depends for its determination of originality upon the descriptive ascertainment of "patterns," as for example those of "characters and sequence of incident." Nichols v. Universal Pictures Corp., 45 F.2d 119, 121 (2d Cir. 1930).

140. Social Register Ass'n v. Murphy, 129 F. 148 (C.C.D.R.I. 1904); 2 P. GoldSTEIN, supra note $45, \S \S 12.0-12.2 ; 1 \mathrm{M}$. NIMMER, supra note $45, \S \S 14.01-14.04$.

141. The general common law rule is that torts relating to property will not support recovery for mental distress unless there are involved "the types of preexisting relationships which give rise to a duty of care [and] involve an aspect of trust and confidence," Sher v. Leiderman, 181 Cal. App. 3d 867, 884, 226 Cal. Rptr. 698, 707 (1986), or unless the tort is characterized by "fraud, malice, or like motives, involving intentional conduct." Charlie Stuart Oldsmobile, Inc. v. Smith, 171 Ind. App. 315, 328, 357 N.E.2d 247, 254 (1976).

142. It is of course possible to conceive property in one's name or image as so intimately connected to one's self as to justify damages for emotional distress. But this conception pro tanto denies the detachability of name or image and hence undercuts their legal conceptualization as market property.

143. Canessa, 97 N.J. Super. at 351, 235 A.2d at 75-76. 
ther complicated by the right of publicity, which appears to offer an exact counterpart of the appropriation tort rigorously conceptualized as a property right. ${ }^{144}$

An attractive solution would be to split the appropriation tort into two distinct causes of action, one oriented toward the protection of property, the other toward the protection of dignity. The right of publicity would serve as an appropriate model for the first. Just as common law copyright extends to the objectification of personality contained in casual letters, regardless of the amount of effort required for their production, so the right of publicity can be extended to the objectification of personality carried by one's "name or likeness," regardless of the actual effort required to invest them with market value.

One difficulty with this solution is that it leaves the appropriation tort, as presently defined, resting upon the inadequate foundation of descriptive privacy. It is now clear that the appropriation tort's incorporation of descriptive privacy was meant to compromise between property and dignitary rationales for the tort. But it has served that function poorly, causing "an intermingling or confusion of the right of privacy and the right of control of the commercial aspects of one's identity."145 To focus clearly upon the protection of dignity, therefore, the appropriation tort must be reformulated in terms of normative privacy, as it originally was in the first Restatement. ${ }^{146}$ As a practical matter this would mean including as an element of the tort the requirement that a defendant's use of a plaintiff's name or likeness be "highly offensive to the reasonable person." ${ }^{147}$ Such a requirement would orient the

144. J. Thomas McCarthy attempts to distinguish appropriation from the right of publicity with the following useful chart:

$\begin{array}{lll} & \begin{array}{l}\text { Appropriation } \\ \text { (Privacy) }\end{array} & \begin{array}{l}\text { Right of } \\ \text { Publicity }\end{array} \\ \text { Infringing Act } & \text { Unpermitted } & \text { Unpermitted } \\ & \text { Use of Identity } & \text { Use of Identity } \\ \text { Impact } & \text { Upon Personal } & \text { Upon Property } \\ & \text { Dignity } & \text { Right in Persona } \\ \text { Measure of } & \text { Mental/Physical } & \text { Damage to the } \\ \text { Damage } & \text { Injury } & \text { Value of Identity/Persona }\end{array}$

J. MCCARTHY, supra note $106, \S 5-63$.

145. Hirsch v. S.C. Johnson \& Son, Inc., 90 Wis. $2 d$ 379, 387, 280 N.W.2d 129, 132 (1979).

146. See supra note 10 and accompanying text.

147. See supra notes 39-40, 42 (comparing RESTATEMENT (SECOND) OF TORTS $\$ \$$ 652B, 652D, 652E (1976)). 
legal definition of the tort toward the social norms deemed necessary for the integrity of personality, thereby justifying compensation for emotional injury.

If the torts of appropriation and right of publicity were to be clearly distinguished and analytically focused in this manner, a second difficulty would arise. We must ask whether we as a society desire the law to conceptualize personality in the manner defined by either of these torts. The tort of appropriation makes sense only on the presupposition that we inhabit a society supported by a coherent structure of communal norms. Yet such a structure may be purely fictitious in a culture as diverse and dynamic as our own. Warren and Brandeis could, with the blithe confidence of aristocratic preeminence, speak for a Brahmin vision of community. But for whom can the tort of appropriation now speak? What community can it establish as legally authoritative? Conversely, with respect to the right of publicity, we must inquire whether we wish the law to create a social structure in which our very names and images have become alienable commodities. Ought the law to facilitate and encourage such an intimate penetration of market standards? One hardly requires sophisticated Marxist accounts of the alienation and reification of the modern self in order to perceive the danger. ${ }^{148}$

Current doctrine strongly suggests that we wish the law to conceive persons as situated simultaneously within two distinct forms of social structure: the matrix of community norms presupposed by appropriation and the arena of market commodification presupposed by the right of publicity. I suspect that this bifurcated vision can be maintained only because community norms have assimilated to such a great extent the standards of the market. We place moral value on the active, enterprising self, and we view the market as establishing the social conditions necessary for its development. ${ }^{149}$ But it is also true that this bifurcated vision is less stable than it might appear. Even if the market is conceptualized as a form of community life, it is a community that differs in fundamental respects from that presupposed by the tort of appropriation. Appropriation valorizes those aspects of personality that are embedded within social norms; the right of publicity valorizes

148. For a classic text, see G. Lukács, History and Class Consciousness: StudIES IN MARXist Dialectics (R. Livingstone trans. 1968).

149. It is for this reason that the institution of property always tends at its edges to verge toward nonmarket normative commitments. See Radin, supra note 119. 
instead those aspects of personality that remain autonomous from and potentially transformative of those norms.

Because appropriation and the right of publicity flow from such very different moral commitments, it may not be sufficient simply to make either tort available at the election of a plaintiff. ${ }^{150}$ In certain circumstances we may want the right of publicity to efface appropriation. When a plaintiff sells the rights to her image, for example, she transforms that image into a market commodity, a thing that is detached from her concrete person. Even if the plaintiff sells her image for only certain purposes, and even if a defendant exceeds those purposes in highly offensive ways, damages for mental distress may not be appropriate because we might regard the plaintiff's image as having been removed from the matrix of community standards that justify and sustain the tort of appropriation. These standards bind together person and image; and hence are incompatible with the commodification of that image. There is sharp internal contradiction in the position of a plaintiff who alienates and objectifies her image and simultaneously claims that it is integral to her very identity in the manner presupposed by the tort of appropriation. ${ }^{151}$

Market effacement of the tort of appropriation would be similar to the preemption suffered by the tort within the structure of public discourse defined and sustained by the first amendment. The Constitution maintains public discourse as a realm within which speakers and audiences can exercise rational autonomy, ${ }^{162}$ and for this reason the tort of appropriation is almost universally suspended when names or images are used within the media of that discourse. ${ }^{163}$ These limitations on the tort vividly illustrate 5.8 .

150. This is essentially McCarthy's solution. See J. McCARTHY, supra note $106, \S$

151. It is possible, of course, to conceive the tort of appropriation like the Continental "Droit Moral," which recognizes artists' personality interests in their work that survive market sale. See S. Halpern, The Law of Defamation, Privacy, Publicity and "MORAL Rights" 615-50 (1988); Merryman, The Refrigerator of Bernard Buffet, 27 HASTiNGS L.J. 1023 (1976). But then we must have some understanding as to how, with respect to a particular plaintiff, name or image can simultaneously be both external to identity and yet integral to it.

152. See Post, supra note 94, at 731-39; Post, supra note 38, at 626-44.

153. See, e.g., Loft v. Fuller, 408 So.2d 619, 623 (Fla. Dist. Ct. App. 1981); Leopold v. Levin, 45 Ill. $2 d$ 434, 259 N.E.2d 250 (1970). The structural incompatibility between the tort of appropriation and public discourse is so telling that most courts have refused to apply the tort to public discourse even in the absence of explicit constitutional compulsion. See, e.g., Tellado v. Time-Life Books, Inc., 643 F. Supp. 904, 908-10 (D.N.J. 1986); Arrington v. New York Times Co., 55 N.Y.2d 433, 440-42, 434 N.E.2d 1319, 1322-23, 449 
the systemic tension between social structures legally constructed to facilitate the exercise of autonomy and social structures legally constructed to maintain the forms of respect owed to the embedded self. The legal structure of market property, we might say, is specifically designed to sustain volitional rather than rational autonomy; its point is to facilitate a self that acts upon the external world. But the analogies between the market and public discourse are clear enough; they in fact illuminate the otherwise puzzling leniency with which the first amendment has been interpreted to allow restrictions on public discourse based upon property rationales. ${ }^{154}$

If, in certain circumstances, the right of publicity may efface appropriation, the converse may also be true. Although market standards have to a large extent become morally valorized, they may nevertheless radically conflict in particular instances with older and deeper forms of community norms. The right of publicity in effect divides a person into two. On the one side there is the objectified image, the persona, which has become a thing of value capable of being owned and transferred. On the other there is what Holmes would call the "natural personality,"155 which is acknowledged primarily in its capacity to generate through effort new and different persona. Merely to observe this demarcation, however, is to raise the possibility that natural personality might in certain circumstances become intolerably enthralled by the objects of its creation.

The possibility is dramatically illustrated by the case of Chris Costner Sizemore, a well-known victim of multiple personality disorder. In 1955 Sizemore signed a contract with 20th Century Fox, in which she assigned to the studio "all . . . rights to my life story, including without limitations in and to all versions of my life story heretofore published or hereafter published and unpublished versions thereof."156 Fox subsequently used Sizemore's life story as the basis for its successful movie The Three Faces of Eve. ${ }^{157}$ Although the movie ended on a happy note, Sizemore was

N.Y.S.2d 941, 943-45, (1982); Koussevitzky v. Allen, Towne \& Heath, 188 Misc. 479, 68 N.Y.S.2d 779 (N.Y. Sup. Ct.), affd, 272 A.D. 759, 69 N.Y.S.2d 432 (1947).

154. See supra notes 94,108 \& 119.

155. O.W. Holmes, The Common Law 267 (M. Howe ed. 1963).

156. Hirshon, Eve's Final Face, Boston Globe, June 18, 1989, Magazine, at 24; see Note, My Life. My Story, Right? Fashioning Life Story Rights in the Motion Picture Industry, 12 Сомм/ENT L.J. 627 (1990).

157. See Note, supra note 156, at 627; Hicks, Whose Life is Eve's, Anyway, NAT'L 
not in fact cured in 1955. ${ }^{168}$ In August of 1989, finally recovered, Sizemore published an updated autobiography, the rights to which Sissy Spacek wished to purchase to make into a film. ${ }^{159}$ The project was aborted, however, when Fox objected, claiming "to own all rights to Ms. Sizemore's life."160 Sizemore filed suit, alleging that she had not and could not have assigned away the rights to her life after 1955. Fox defended on the grounds that it held the "sole rights to portrayal of Mrs. Sizemore's life in its entirety, with no time limit."161

The Sizemore case sharply illuminates the point that property rights can be exercised in highly offensive ways, deeply damaging to the kind of community norms that appropriation is designed to uphold. ${ }^{162}$ To borrow from the vocabulary of a related area of tension between market rules and community standards, it would seem to be unconscionable to allow the objectification and alienation of a person's entire narrative history. Sizemore's complaint-"I want to own myself before I die"163 -is simply too compelling to be denied. Surely if we care at all about the form of life that appropriation acknowledges and defends, the social structures sustained by the right of publicity must in such circumstances yield to those upheld by appropriation.

It is not enough, therefore, simply to split the contemporary appropriation tort into two, half protecting dignity and half property, and leave the election to plaintiffs. In the end, there will be times when we will be forced to choose the circumstances in which we will protect one aspect of personality or the other. This brief paper is not the occasion to think through in detail the dense and textured interaction between appropriation and the right of publicity. That enterprise ought to be pursued by those with a finer grasp of its detail. It is sufficient for my purposes to reaffirm Warren and Brandeis's faith in the eternal capacity of the common

\section{L.J., Oct. 23, 1989, at 8.}

158. For example, the contract she signed with Fox had spaces for the signature of five of Sizemore's personalities. Hirshon, supra note 156, at 24.

159. Id.

160. Id.

161. Brozan, The Real "Eve" Sues to Film the Rest of Her Story, N.Y. Times, February 7,1989, \& C, at 13, col. 1 .

162. One might also say about the Sizemore case that it illustrates how the right of publicity can, in certain circumstances, self-destruct, because commodified personality returns to smother the very intellectual effort it was designed to foster.

163. Hicks, supra note 157 , at 8 . 
law "to meet the demands of society."164

\section{CONCLUSION}

Warren and Brandeis's great achievement was to discern that our social life required legal protection for the dignitary as well as the proprietary aspects of personality. It is for us to decide, in the spirit of their magnificent contribution, whether the social prerequisites necessary to maintain individual dignity are sufficiently stable and coherent to merit legal embodiment, and whether and how these prerequisites ought to intersect with those of the marketplace.

The legacy of Warren and Brandeis contains both insight and warning. The insight is that the law is a powerful instrument for fashioning the forms of our social life. The warning is that we must take care that the forms of life the law creates are those we desire to inhabit.

164. Warren \& Brandeis, supra note 1, at 193. 